\title{
CAN DEVELOPING COUNTRIES HANDLE THE MENTAL BURDEN DUE TO THE LOCKDOWN SITUATION? UNDERSTANDING THE UNCERTAINTY AND MANAGEMENT OF COVID-19 PANDEMIC
}

\author{
Jyotsna Pandey?', Shohini Chakraborty2, Imon Chakraborty³, Pratik Ghosal4, Neelam Singh5, \\ Sukanta Majumdar² \\ 1. Department of Microbiology, St. Xavier's College, Kolkata, West Bengal, India \\ 2. Microbiology and Microbial Biotechnology Laboratory, Department of Botany, University of Gour Banga, Malda, West Bengal, \\ India. \\ 3. UQ-IITD Academy of Research, Indian Institute of Technology, Delhi, India \\ 4. Department of Computer Science, University of Wroclaw, Wroclaw, Poland \\ 5. School of Physical and Decision Science, Department of Physics, Babasaheb Bhimrao Ambedkar University, Lucknow, Uttar \\ Pradesh, India
}

Correspondence: shohini.chakraborty@gmail.com

\section{ABSTRACT}

\section{BACKGROUND}

Coronavirus (Covid-19) pandemic can be referred to as a life-threatening war where every country is fighting with an invisible untold enemy. Realizing the disease severity and managing the prevention is crucial in current situations. Hence, it is time to follow the lockdown protocol until the situation improves worldwide.

\section{METHOD}

We have searched all the possible validated resources such as WHO, governmental data-sharing portal, news media, blogs, and existing empirical studies. We identified the significant inputs from social media platforms provided by healthcare entrepreneurs, clinicians, and interrelated different domain experts. Here we qualitatively narrated an in-depth understanding of the phenomena and proposed a few steps to deal with the mental burden in developing country context.

\section{RESULT}

There must be some effective strategy to reduce the mental burden and availability of the health consultancy services continuously to deal with such vulnerable situations. Telehealth is one such solution in a developed country where the healthcare system is well equipped to offer such services.

\section{CONCLUSIONS}

Here, we have presented a few proposed steps that can be adapted/practiced dealing with a similar situation in developing and densely populated nation like India. This approach may help to deal with such emergencies and challenges for healthcare management in lockdown conditions.

\section{KEYWORDS}

Coronavirus, Covid-19, Pandemic, Lockdown, Mental health

\section{CRISP UNDERSTANDING AND MANAGEMENT OF COVID-1}

This study briefly explains the coronavirus and specifically Covid-19, possible precautions, and preventive measures. The study proceeds with a genomic structure and infection mechanism of SARS-COV-2, disease outbreak, its etiology, epidemiology, transmission phenomenon, and crucial 
steps in disease management to tackle mental burden during the complete lock-down situation.

\subsection{GENOMIC STRUCTURE AND INFECTION MECHANISM OF SARS-COV-2}

Coronaviruses are single-stranded RNA viruses containing 80-120 nm in diameter. Coronaviruses mainly recognize their corresponding receptors on target $B$ cells because SARS-CoV2 uses angiotensin-converting enzyme 2 (ACE2) as its receptor through $S$ proteins on their surface and after that virus entry to the cells and results in infection. Four types of coronavirus have been found, such as acoronavirus, $\beta$-coronavirus, $\delta$-coronavirus, and $Y$ coronavirus. [1] The whole-genome sequence of SARSCOV2 and SARS is approximately $79 \%$ similar. So that SARSCoV2 is closer to the SARS-like bat coronaviruses (MG772933) than SARS-CoV. [2]The whole mechanism of SARS-CoV2 firstly infects humans via S-protein bind to the ACE2 receptor, the strength of this interaction for risk of human transmission, and how SARS-CoV-2 causes organ damage to remain unknown still today. Present research explains that this SARS-CoV-2 virus has a very fast capacity to transmission in humans as compared with SARS-CoV.[3,4] Because of the higher affinity of SARS-COV-2 binding to ACE2, so that ACE2 may be a potential candidate for the treatment of COVID-19.

\subsection{OUTBREAK}

The viral disease is generally caused when an infectious viral particle (virion) invades a host body or cell. Scientist rigorously works and develop vaccines against it. The virus keeps on changing its genome continuously, and later, the same particle is proved to be life-threatening. Similarly, the Coronavirus was initially discovered in the late 1960s. [5,6] It was first recognized as an infectious bronchitis virus. The first outbreak of SARS CoV had begun in Asia in 2003, in which more than 8000 people suffered from the deadly disease. [7] The next identified situation was Middle East Respiratory Syndrome, which was reported repeatedly in 2012, 2015, and 2018. [8,9]

In December 2019, a coronavirus outbreak was accounted for in Wuhan, China. Based on the research, the International Committee on Taxonomy of Viruses has denoted this virulent virus as SARS-CoV-2[W 56-60]. Tentatively, as of 23rd July 2020, more than 15,415,727 people have been reported fighting with this disease, and 631,164 lives are lost. [10]

\subsection{ETIOLOGY}

Etiology [11] is the elucidation of the causation of any disease. In medicine, etiology explains the ground behind any disease. It also describes the factors causing illness.

Coronavirus is a large, spherical particle with a diameter of $120 \mathrm{~nm}$ having surface projections. [10,12] The envelope of the virus comprises a lipid bilayer in which spike structural protein is grounded. Beta coronavirus subgroup A, a subset of the coronavirus also has a spike-like protein referred to as hemagglutinin esterase. [13] Coronavirus has a singlestranded RNA genome, approximately 27-34 kilobase pairs in size. [14] The nucleocapsid is a protein-bound in the RNA genome along with an envelope of the lipid bilayer, and membrane protein protects the virus outside the host cell. [15]

Infection initiates when the virus attaches to a host cell, and the genetic material is transferred into the host cell. Replication, transcription, and translation of viral genetic material (i.e., RNA) and essential proteins (i.e., nucleocapsid, spike protein), respectively takes place inside the host cell. Afterward, the progeny viruses assemble and get released from the host cell by exocytosis and proceed to infect new host cells. In this way, a single virus particle spreads the infection throughout the body. $[16,17]$

\subsection{EPIDEMIOLOGY}

Epidemiology is the field of study that depicts the distribution patterns and the disease and health conditions for a population. Approximately15.4 million cases of COVID-19 have been reported globally from December 2019 to 23rd July 2020. Since the first report in Wuhan China, globally, more than 630,781 patients have lost their lives due to the deadly coronavirus. [10] Initially, positive cases were reported from Hubei and its surrounding provinces, but gradually, it reflected in other areas throughout China. [18]

Gradually, the spread of COVID-19 rolled out in other countries around the globe. Positive cases were initially found mainly among the travellers from China or who had been coming in contact with them. However, In July 2020, COVID-19 broke out in the following countries outside of China, i.e., Italy, Spain, the USA, Germany, Iran, France, South Korea, Switzerland, the UK, Netherland, India and many more. Positive cases are also detected and increasing day by day in developing countries, for instance, India, Pakistan, Bangladesh, Sri Lanka, and Russia, 
etc. COVID-19 has become a life-threatening pandemic situation globally $[9,10]$.

\subsection{TRANSMISSION}

Existing research revealed that mainly three types of the transmission process, such as symptomatic, presymptomatic, and asymptomatic. It has been accounted that the COVID-19 virus can survive for hours to a few days on surfaces such as door handle and electric switches. Notably, this virus remains infectious on plastic and stainless steel for three days, on copper for four days, and on cardboard for at least one day. Limited research has shown that the effectiveness of this phenomenon varies with temperature and humidity. Previous researchers had confirmed that this deadly enemy spread only via respiratory droplets, not through the air, water, or food. [19] Recent research has noted that this viral infection may be spread by air in a confined place. Airborne transmission is different from droplet transmission. Virus droplet nuclei $<5$ $\mu \mathrm{m}$ in diameter can remain in the air for a prolonged time. It can also travel over $1 \mathrm{~m}$ of distance and transmit to other individuals.

\section{Symptomatic transmission}

Symptomatic transmissionoccurs from a person who has developed signs and symptoms of COVID-19 virus infections. This virus is transmitted via respiratory droplets when an infected person sneezes and coughs without following proper hygiene. Any kind of direct or indirect contact of that droplet to a healthy person causes the transmission of this contagious disease. It is also spread by touching any contaminated surface, followed by touching of face, mouth, nose, and eyes. [22]

\section{Pre-symptomatic transmission}

COVID-19 virus incubation period is five to six days on average, which is the period of viral exposure (becoming infected) and symptom onset. But in some cases, this incubation time may be up to 14 days. In maximum cases, people can test positive for COVID-19 from 1-3 days before they develop symptoms. [23] This period is also known as the pre-symptomatic period when an infected individual can be contagious. Hence, transmission from a presymptomatic case can occur before symptom onset. [2429] So there was a chance that people infected with COVID-19 could transmit the virus before significant symptoms develop.

\section{Asymptomatic transmission}

In asymptomatic transmission, the virus transmission takes place from an infected person who does not have any viable symptoms. However, new evidence is emerging in this type of transmission, to understand the phenomena profoundly. [29]

\subsection{DISEASE MANAGEMENT}

The strain of the Covid-19 virus is unique; as we know, there are no well-established management procedures to curb this epidemic. Prevention is the only effective method to deal with such situations. WHO has published the RNA testing protocol to check whether a person is infected with this virus or not? But as the number is increasing globally, it is quite impossible to test individuals with RNA testing methods. [30] For a developing \& populous country, it seems impossible to avail diagnosis to all in the current scenario. Radiology and other imaging technology can play a role in the diagnosis, but its use is not completely confirmed to detect positive cases so far. [31]

WHO has suggested self-preventive measures to combat COVID-19 and protect oneself. [32] These are as follows:

- Respiratory hygiene- Use of mask, covering the mouth while coughing and sneezing. [33]

- $\quad$ Frequent Hand washes- Proper washing and sanitization of hands. [32]

- Refraining from touching the face- Touching eyes, nose, and mouth is strictly prohibited without washing the hand. [34]

- Avoid touching any surfaces-Preferably avoid touching any unknown surface and, if required, then sanitize or wash the hands effectively. [32]

- Social distancing-Maintain distance from everyone to maintain individual and social safety. [35]

- Self-quarantine- avoid unnecessary social gatherings and try to stay indoors. [36]

\section{CHALLENGES IN UNCERTAINTY AND PANDEMIC MANAGEMENT}

Almost every country around the world faces various challenges in disease management, as well as in implementing its preventive measures. [37] Influenced by the precautions taken by China [38] and South Korea, [39] other countries are attempting to follow similar kinds of models to deal with such dangerous, life-threatening 
situations. Initial exposure (first stage) of a country to the development of the epidemic situation led to the implementation of various preventive measures and protocols to protect the population. But the transition from second to the third stage of the pandemic caused the declaration of complete lockdown from every level [40] in affected countries. People find it very difficult to handle such a lockdown situation for more than a few days. One class of people don't understand the actual meaning of lockdown. [41] Another class of people focuses on hoarding unnecessary foodstuffs. Thus, it creates a scarcity of resources and initial social gatherings in the market and public places. [42] People from different financial capacities face several mental burdens, and it increases gradually as the period of complete lockdown is extended. [43]

Developed countries such as Australia have implemented the telehealth facility to reduce the mental stress in Covid19. Australia has a well-established telemental health service network that provides online mental health services in remote locations to provide essential information and deal with the mental burden of the suffering people. [4447] Developing countries such as India, Bangladesh, Pakistan, Sri Lanka, and many others have no such facility to deliver mental health services, and such countries might face huge mental burden in the future. [48] Vietnam has relatively fewer COVID-19 cases per 1 million population. Successful strategies include accurate health information [49], establishment grassroots health care system [50], and the deployment of health collaborators to work with villagers in rural areas. [51] China has implemented a careful precaution system to protect workers (e.g., proper ventilation, wear of face mask), and it was associated with better mental health. [52]

\section{POSSIBLE STEPS TO CURB THE MENTAL STRESS OF PEOPLE FROM A DEVELOPING COUNTRY, INDIA}

As researchers, here we have tried to propose a few measures to deal with these situations. These measures can aid in reducing the mental burden to some extent among the people from India. These offerings are:

Firstly- Provide free internet services to engage the common and mainly rural people who can use the internet so that they can keep themselves engaged and reduce any mental stress. Previous studies found that obtaining health information from the Internet was associated with better mental health during the COVID-19 pandemic. $[53,54]$

Secondly-A huge number of people in India watch family serials and series. Due to lockdown, no new episode is aired which is making the routine quite mundane for millions of peoples. They do not even know how to stay indoor throughout the day. To tackle such situations, authorities can provide various entertainment services on television free of cost until the pandemic situation reduces. Many people use different paid subscription services such as Amazon Prime, Netflix, Voot.[55] If the authority will provide free services or cut down the subscription cost to lowest at least for a month, then more people can be indulged in such subscriptions. These shall reduce or divert the mental burden of millions of people.

Thirdly- Primary and secondary level healthcare centres should provide cost-free online consultation in regional language to every corner of the country to spread awareness and reduce anxiety among the public through online cognitive behaviour therapy. [56] This informative consultation may induce awareness towards the fake social media posts and reduce the panic and mental burden of people. Specific measures may help the old age population who do not entirely understand the pandemic situation and encourage them to stay safe.

Fourthly-Several mental and physical health boost-up programs can be started online to engage many people. This can be efficacious by spreading its potency though famous faces, for instance, politicians, commercial stars, and motivational speakers. The online platform and social media have a huge potential to employ such engaging events among the common people.

\section{OPTIMISTIC VIEWPOINT}

There is a rapidly increasing number of positive cases and a sharp leap in the mortality rates associated with Covid19. We must be aware of the mental stress and burden caused by this pandemic. A recent publication has shown that telehealth is adequately suitable for mental health management in a pandemic situation. Free internet services with engaging entertainment programs along with the teleconsultancy services might help the public to tackle the mental stress in the national emergency like situation due to the Covid-19 pandemic. Awareness and mental 
health enhancement can be a quite effective step to reduce the monotony and panic situation among the common mass of the nation. Such a strategic lockdown will reduce the risk of infection along with balancing the mental health care of the population.

Additionally, another critical dimension, socioeconomic wellbeing needs to address to curb mental stress of the mass populace of the developing countries. Learning new skills and self-reliance are the primary factor in surviving in the job recession time. For instance, in a developing country like India, the government has announced three lakh core collateral-free loan scheme for small and medium enterprises (SMEs). In developing countries, state and central governing authorities have been distributing free staple food through the public distribution system among all the population, according to their socioeconomic status and needs. However, as rapidly growing cases of COVID-19, there is a need to extend the free food distribution scheme for the next couple of months or until the pandemic over. We must be aware of the mental stress and burden caused due to this pandemic. [57]

\section{ACKNOWLEDGEMENT}

The authors acknowledge Lifeline Health Care, ChanchalMalda, India, for providing information regarding mental stress conditions among the population of remote area and local epidemic management.

\section{CONFLICTS OF INTEREST}

The authors have declared that there is no conflict of interest.

\section{Reference}

1. Chan JF, To KK, Tse H, Jin DY, Yuen KY. Interspecies transmission and emergence of novel viruses: lessons from bats and birds. Trends Microbiol, 2013; 21:544555. doi: https://doi.org/10.1016/j.tim.2013.05.005

2. Wu A, Peng $Y$, Huang B, Ding X, Wang X, Niu P, Meng J, Zhu Z, Zhang Z, Wang J, Sheng J.Genome composition and divergence of the novel coronavirus (2019-nCoV) originating in China. Cell Host Microbe 2020;27 (3): 325-328. doi: https://doi.org/10.1016/j.chom.2020.02.001

3. Hoffmann M, Kleine-Weber H, Krüger N, Müller M, Drosten C, Pöhlmann S. The novel coronavirus 2019 (2019-nCoV) uses the SARS-coronavirus receptor ACE2 and the cellular protease TMPRSS2 for entry into target cells. bioRxiv, 2020:929042. doi: https://doi.org/10.1101/2020.01.31.929042

4. Wrapp D, Wang N, Corbett KS, Goldsmith JA, Hsieh CL, Abiona O, Graham BS, McLellan JS. Cryo-EM structure of the 2019-nCoV spike in the prefusion conformationScience (New York, NY), 367 (6483) (2020), pp. 1260-1263. doi: 10.1126/science. abb2507

5. Kahn J, Mclntosh K. History and recent advances in coronavirus discovery. Pediatr Infect Dis J 2005; 24 (1 1):223-227, doi:10.1097/01.inf.0000188166.17324.60

6. Geller C, Varbanov M, Duval RE. Human coronaviruses: insights into environmental resistance and its influence on the development of new antiseptic strategies. Viruses 2012; 4 (11): 3044-68. doi:10.3390/v4113044

7. Smith RD. Responding to global infectious disease outbreaks: lessons from SARS on the role of risk perception, communication and management. Soc Sci Med 2006; 63(12):3113-23. doi:10.1016/j.socscimed.2006.08.004

8. Middle East respiratory syndrome coronavirus (MERSCoV)-Republic of Korea. World Health Organization. 2016.

9. Coronavirus COVID-19 Global Cases by Johns Hopkins CSSE. ArCGIS. Johns Hopkins CSSE. 2020.

10. Novel Coronavirus (2019-nCoV) situation reports World Health Organization (WHO)

11. Etiology of Disease: Definition \& Example - Video \& Lesson Transcription.

12. Fehr AR, Perlman S. Maier HJ, Bickerton E, Britton $P$ (eds.). An Overview of Their Replication and 
Pathogenesis; Section 2 Genomic Organization. Methods in Molecular Biology. Springer.2015; 1282: 123. doi:10.1007/978-1-4939-2438-7_1

13. Chang CK, Hou MH, Chang CF, Hsiao CD, Huang TH. The SARS coronavirus nucleocapsid protein--forms and functions. Antiviral Res 2014; 103: 39-50. doi:10.1016/j.antiviral.2013.12.009.

14. Sexton NR, Smith EC, Blanc H, Vignuzzi M, Peersen OB, Denison MR. Homology-Based Identification of a Mutation in the Coronavirus RNA-Dependent RNA Polymerase That Confers Resistance to Multiple Mutagens. J Virol 2016; 90 (16): 741528.doi:10.1128/JVI.00080-16

15. Neuman BW, Kiss G, Kunding AH, Bhella D, Baksh MF, Connelly S, Droese B, Klaus JP, Makino S, Sawicki SG, Siddell SG.A structural analysis of $M$ protein in coronavirus assembly and morphology. J Struct Biol 2011; 174 (1): 11-22. doi:10.1016/j.jsb.2010.11.021

16. Fehr AR, Perlman S. Coronaviruses: an overview of their replication and pathogenesis. Methods $\mathrm{Mol}$ Biol 2015; 1282:1-23. doi: 10.1007/978-1-4939-2438-7_1

17. Snijder EJ, Bredenbeek PJ, Dobbe JC, Thiel V, Ziebuhr J, Poon LL, Guan Y, Rozanov M, Spaan WJ, Gorbalenya AE. Unique and conserved features of genome and proteome of SARS-coronavirus, an early split-off from the coronavirus group 2 lineage. J Mol Biol 2003; 331 (5): 991-1004. doi:10.1016/\$00222836(03)00865-9

18. "Q\&A on coronaviruses". World Health Organization. 2020.

19. Majumder M andMandl KD. Early Transmissibility Assessment of a Novel Coronavirus in Wuhan, China. Harvard University - Computational Health Informatics Program - Posted: 24 Jan 2020.

20. Cheng VC, Wong SC, Chen JH, Yip CC, Chuang VW, Tsang OT, Sridhar S, Chan JF, Ho PL, Yuen KY. Escalating infection control response to the rapidly evolving epidemiology of the Coronavirus disease 2019 (COVID-19) due to SARS-CoV-2 in Hong Kong. Infect Control Hosp Epidemiol. 2020.

21. Ong SW, Tan YK, Chia PY, Lee TH, Ng OT, Wong MS, MarimuthuK.Air, surface environmental, and personal protective equipment contamination by severe acute respiratory syndrome coronavirus 2 (SARS-CoV-2) from a symptomatic patient. JAMA. 2020.
22. Transmission of Novel Coronavirus (2019-nCoV). CDC 2020.

23. World Health Organization. Report of the WHO-China Joint Mission on Coronavirus Disease 2019 (COVID-19) 16-24 February 2020. Geneva: World Health Organization; 2020 Available from: https://www.who.int/docs/defaultsource/coronaviruse/who-china-joint-mission-oncovid-19-final-report.pdf

24. Kimball A, Hatfield KM, Arons M, James A, Taylor J, Spicer K, Bardossy AC, Oakley LP, Tanwar S, Chisty Z, Bell JM. Asymptomatic and Presymptomatic SARSCoV-2 Infections in Residents of a Long-Term Care Skilled Nursing Facility - King County, Washington, March 2020. MMWR, 3 April 2020, 69(13);377-381.

25. Yu P, Zhu J, Zhang Z, Han Y. A familial cluster of infection associated with the 2019 novel coronavirus indicating possible person-to-person transmission during the incubation period. J Infect 2020 doi: 10.1093/jiaa077

26. Huang R, Xia J, Chen Y, Shan C, Wu C. A family cluster of SARS-CoV-2 infection involving 11 patients in Nanjing, China Lancet Infect Dis 2020 doi: $10.1016 /$ S1473-3099(20)30147-X

27. Pan $X, C h e n D$, Xia $Y$ et al. Asymptomatic cases in a family cluster with SARS-CoV-2 infection. Lancet Infect Dis 2020 doi: 10.1016/ S1473-3099(20)30114-6

28. Tong Z-D, Tang A, Li K-F, Li P, Wang H-L, Yi J-P, Zhang $Y L$, Yan JB. Potential presymptomatic transmission of SARS-CoV-2, Zhejiang Province, China, 2020. Emerg Infect Dis. 2020 doi: 10.3201/eid2605.200198

29. Wei WE, Li Z, Chiew CJ, Yong SE, et al. Presymptomatic Transmission of SARS-CoV-2 - Singapore, January 23March 16, 2020. MMWR, 1 April 2020/69.

30. Laboratory testing of 2019 novel coronavirus (2019$\mathrm{nCoV}$ ) in suspected human cases: interim guidance, 2020.

31. Li Y, Xia L. Coronavirus Disease 2019 (COVID-19): Role of Chest CT in Diagnosis and Management. AJR Am J Roentgenol 2020; 1-7.doi:10.2214/AJR.20.22954. PMID 32130038

32. Advice for public. World Health Organization. 2020.

33. Coronavirus disease (COVID-19) advice for the public: When and how to use masks". World Health Organization. 
34. Coronavirus public information campaign launched across the UK". Government of the United Kingdom.

35. Prevention \& Treatment. US Centers for Disease Control and Prevention. 2020.

36. Stay at home: guidance for households with possible coronavirus (COVID-19) infection. GOV.UK. 2020.

37. Lai CC, Shih TP, Ko WC, Tang HJ, Hsueh, PR. Severe acute respiratory syndrome coronavirus 2 (SARS-CoV2) and corona virus disease-2019 (COVID-19): the epidemic and the challenges. Int J Antimicrob Agents 2020; p. 105924.

38. Lewis IK, Zhou M, Wang EJY. The China Experience Understanding the Evolution of the COVID-19 Crisis.https://www.mayerbrown.com/en/perspectivesevents/publications/2020/03/the-china-experienceunderstanding-the-evolution-of-the-covid-19-crisis

39. Normile D. Coronavirus cases have dropped sharply in South Korea. What's the secret to its success?2020. https://www.sciencemag.org/news/2020/03/coronavi rus-cases-have-dropped-sharply-south-korea-whatssecret-its-success

40. Mayberry K, Allahoum R, Siddiqui U. India locks down 1.3 billion people: Live coronavirus updates. https://www.aljazeera.com/news/2020/03/uk-closeswarns-pandemic-accelerating-live-updates200323234651419.html

41. Italy charges more than 40,000 people with violating lockdown.

https://www.theguardian.com/world/2020/mar/18/ita ly-charges-more-than-40000-people-violatinglockdown-coronavirus

42. DON'T PANIC :Here's how much food you need to stockpile for two weeks in self-isolation due to coronavirus by Sara Benwells. https://www.thesun.co.uk/money/1 1095369/coronavir us-stockpile-guide-how-much/

43. Bose A, Gunjan RK. Panic, Anxiety, Depression: What Coronavirus Lockdown Means for India's Mental Health.https://www.news18.com/news/buzz/panicanxiety-depression-what-coronavirus-lockdownmeans-for-indias-mental-health-2548869.html

44. Australian Government Department of Health. Coronavirus (COVID-19). 2020. https://www.health.gov.au/health-topics/novelcoronavirus-2019-ncov
45. Maunder RG. Was SARS a mental health catastrophe? Gen Hosp Psychiatry 2009;31:316-317.

46. Garcia-Lizana F, Munoz-Mayorga I. Telemedicine for depression: A systematic review. PerspectPsychiatr Care 2010; 46:119-126.

47. Rees CS, Maclaine EJAP. A systematic review of videoconference-delivered psychological treatment for anxiety disorders. Aust Psychol 2015; 50:259-264.

48. How to deal with the stress of COVID-19 in the time of lockdowns. https://www.firstpost.com/health/how-todeal-with-the-stress-of-covid-19-in-the-time-oflockdowns-8177091.html

49. Le HT, Nguyen DN, Beydoun AS, Le XT, Nguyen TT, Pham QT, Ta NT, Nguyen QT, Nguyen AN, Hoang MT, Vu LG. Demand for Health Information on COVID-19 among Vietnamese. Int J Environ Res Public Health. 2020;17(12): E4377. doi: 10.3390/ijerph17124377

50. Tran BX, Hoang MT, Pham HQ, Hoang CL, Le HT, Latkin CA, Ho CS, Ho RC. The operational readiness capacities of the grassroots health system in responses to epidemics: Implications for COVID-19 control in Vietnam. J Glob Health. 2020;10(1):01 1006. doi: 10.7189/jogh.10.011006

51. Tran BX, Phan HT, Nguyen TP, Hoang MT, Vu GT, Lei HT, Latkin CA, Ho CS, Ho RC. Reaching further by Village Health Collaborators: The informal health taskforce of Vietnam for COVID-19 responses. J Glob Health. 2020;10(1):010354. doi:10.7189/jogh.10.010354

52. Tan W, Hao F, Mclntyre RS, Jiang $L$, Jiang $X$, Zhang $L$, Zhao X, Zou Y, Hu Y, Luo X, Zhang Z. Is Returning to Work during the COVID-19 Pandemic Stressful? A Study on Immediate Mental Health Status and Psychoneuroimmunity Prevention Measures of Chinese Workforce [published online ahead of print, 2020 Apr 23]. Brain Behav Immun. 2020; S08891591 (20)30603-6. doi:10.1016/j.bbi.2020.04.055

53. Wang $C$, Pan R, Wan X, Tan $Y, X \cup L$, Ho CS, Ho RC. Immediate Psychological Responses and Associated Factors during the Initial Stage of the 2019 Coronavirus Disease (COVID-19) Epidemic among the General Population in China. Int J Environ Res Public Health. 2020;17(5):1729. doi:10.3390/ijerph17051729

54. Wang C, Pan R, Wan X, Tan Y, XU L, Mclntyre RS, Choo FN, Tran B, Ho R, Sharma VK, Ho C. A Longitudinal Study on the Mental Health of General Population during the COVID-19 Epidemic in China [published 
online ahead of print. Brain Behav Immun. 2020;

S0889-1591 (20)3051 1-0. doi:10.1016/j.bbi.2020.04.028

55. Wayne ML. Netflix, Amazon, and branded television content in subscription video on-demand portals. Media Cult Soc 2018; 40(5), pp.725-741.

56. Ho CS, Chee CY, Ho RC. Mental Health Strategies to Combat the Psychological Impact of COVID-19 Beyond Paranoia and Panic. Ann Acad Med Singapore. 2020:49(3):155-160.

57. Tran BX, Ha GH, Nguyen LH, Vu GT, Hoang MT, Le HT, Latkin CA, Ho CSH, Ho RCM. Studies of novel coronavirus disease 19 (Covid-19) pandemic: A global analysis of literature. Int. J. Environ. Res. Public Health. 2020;17(11): 4095 .doi: https://doi.org/10.3390/ijerph17114095 